\title{
The Influence of Hyper-Alkaline Leachate on a Generic Host Rock Composition for a Nuclear Waste Repository: Experimental Assessment and Modelling of Novel Variable Porosity and Surface Area
}

\author{
Yousef Baqer, et al. [full author details at the end of the article]
}

Received: 25 May 2021 / Accepted: 8 October 2021 / Published online: 27 October 2021

(c) The Author(s) 2021

\begin{abstract}
Deep geological disposal is the preferred solution for long-term storage of radioactive waste in many countries. In a deep repository, cementitious materials are widely used in the structure and buffer/backfill of the repository for the stabilisation of the hazardous materials. The cement acts as a physical barrier and also contributes chemically to waste containment by buffering the groundwater to a high $\mathrm{pH}$, limiting the solubility of many radionuclides. This paper describes an experimental and modelling study which evaluates the geochemical interaction between young cement leachate $(\mathrm{YCL}, \mathrm{pH}=13$ ) and a generic hard rock (in this case Hollington sandstone, representing a 'hard' host rock) during permeation with the leachate, as it drives mineralogical changes in the system. One-dimensional reactive transport was modelled using a mixing cell approach within the PHREEQC geochemical code to identify the essential parameters and understand and scale up the effect of variations in these parameters on the observed geochemical processes. This study also focused on the effects of variable porosity, reactive surface area and pore volume on improving the modelling of rock alteration in the system compared to conventional models that assume constant values for these properties. The numerical results showed that the interaction between the injected hyper-alkaline leachate and the sandstone sample results in a series of mineralogical reactions. The main processes were the dissolution of quartz, kaolinite and k-feldspar which was coupled with the precipitation of calcium silicate hydrate gel and tobermorite-14A (C-S-H), prehnite (hydrated silicate), saponite-Mg (smectite clay) and mesolite (Na-Ca zeolite). The simulation showed that the overall porosity of the system increased as primary minerals dissolve and no stable precipitation of the secondary $\mathrm{C}-\mathrm{S}-\mathrm{H} / \mathrm{C}-\mathrm{A}-\mathrm{S}-\mathrm{H}$ phases was predicted. The variable porosity scenario provides a better fitting to experimental data and more detailed trends of chemistry change within the column. The time and the number of moles of precipitated secondary phases were also improved which was related to greater exposure surface area of the minerals in the sandstone sample to the YCL.
\end{abstract}

\section{Article Highlights}

- The drop in calcium, aluminium and silicate concentrations is mainly due to the formation of calcium silicate hydrate and zeolite minerals as secondary phases. The simulation showed that the overall porosity of the system increased as pri- 
mary minerals dissolve and no stable precipitation of the secondary $\mathrm{C}-\mathrm{S}-\mathrm{H}$ /C-AS-H phases was predicted.

- The dissolution of primary minerals and the precipitation of secondary C-S-H phases had a minimal effect on the $\mathrm{pH}$ values, and this was controlled mainly by the initial fluid chemistry.

- The variable porosity scenario provides a better fitting to experimental data and more detailed trends of chemistry change within the column.

Keywords PHREEQC $\cdot$ Geochemical · Modelling $\cdot$ Mineral $\cdot$ Calcium silicate hydrate

\section{Introduction}

Radioactive waste includes abundant industrial residual materials that require a management plan for their safe disposal and containment, particularly due to their long-lived radioactivity and chemical toxicity. In many countries, the preferred method of radioactive waste disposal is immobilisation in copper or stainless steel canisters and burial in an engineered deep geological disposal facility (Crossland 2007). Cementitious materials are widely used in the structure and buffer/backfill of the repositories as part of a multi-barrier approach for the stabilisation of the hazardous materials. The cement acts as a physical barrier and contributes chemically to waste containment by buffering the groundwater to a high $\mathrm{pH}$, limiting the solubility of many radionuclides (Felipe-Sotelo et al. 2017).

The final assessment of any geological disposal relies on the ability of the host rock to retard the migration of contaminants to isolate them from the biosphere. Therefore, the safety assessment should predict the effect of the released radionuclides on the surrounding environment in the event of failure of the engineered barriers. Once a repository is closed, groundwater will interact with cementitious materials used to form the structure or in the waste form, and create a hyper-alkaline (up to $\mathrm{pH} 13.5$ ) plume over time (Francis et al. 1997; Vasconcelos et al. 2018). This plume will migrate into the host rock, creating a chemically disturbed zone (CDZ). The chemical composition of the alkaline leachate emerging from the repository will continue to evolve over time as more ions are released from the cement minerals. The plume of young cement leachate (YCL) will also change as it migrates and reacts with the host rock minerals. Understanding the geochemical interactions that occur between the leachate and the host rock is critical, in order to define the impact of the hyper-alkaline plume on the geological, mineralogical and physical behaviour of the host rock.

When high-pH leachate from a deep geological disposal facility migrates through a sandstone host rock, both mineral dissolution and precipitation processes will occur, changing the matrix porosity within the CDZ (Chen et al. 2015; Chen and Thornton 2018). Dissolution of primary minerals (e.g. quartz, k-feldspar and aluminosilicate minerals) can increase the matrix porosity. In contrast, the precipitation of secondary clay minerals (e.g. saponite, illite and kaolinite) can reduce the porosity. The precipitated secondary minerals may have different sorption properties than the reacting primary minerals, which is important when considering the potential mobility of radionuclides. Several studies have examined the effects of an alkaline plume on clay minerals (Velde 1965; Eberl and Hower 1977; Mohnot et al. 1987; Chermak 1993; Bauer and Berger 1998). However, the kinetics of silicate mineral dissolution and precipitation kinetics of the secondary calcium silicate hydrate 
(C-S-H) and calcium aluminium silicate hydrate $(\mathrm{C}-\mathrm{A}-\mathrm{S}-\mathrm{H})$ phases in high-pH leachate, is less well known.

The British Geological Survey (BGS) conducted laboratory column experiments to investigate the mineralogical transformations and geochemical processes that may occur when a hyper-alkaline plume flows through sandstone (Small et al. 2016). The experiments provided a conceptual understanding of the processes involved and information on essential parameters that control those processes. Although significant work has been done in the field of radionuclide fate and transport(Silva 1991; Dozol and Hagemann 1993; Savage 1997; Monte et al. 2004; Putyrskaya and Klemt 2007), describing how contaminants migrate through geological formations in which interactions change physical and chemical properties of the host rock remains a challenge. The modelling of multiple geochemical kinetic reactions and the mineralogical evolution associated with hyper-alkaline leachate migration through host rock allows the role of mineral composition and geochemical properties on the chemical affinity and evolution of secondary $\mathrm{C}-\mathrm{S}-\mathrm{H}$ and $\mathrm{C}-\mathrm{A}-\mathrm{S}-\mathrm{H}$ phases to be investigated.

In this study, the results of the column experiment carried out by BGS (Small et al. 2016) are interpreted using the geochemical transport code PHREEQC (Parkhurst and Appelo 2013) and the Lawrence Livermore National Laboratory (LLNL) database included therein. The BGS experiment identified the key kinetic reactions and putative reactive pathways that controlled the primary mineral dissolution, mineral evolution, secondary mineral formation and column effluent evolution. The PHREEQC code can model and scale up multiple kinetic reactions to interpret effects due to variation in leachate chemistry from short duration of the laboratory experiments' to longer timescales. Additional modules were added to PHREEQC to calculate porosity changes resulting from the dissolution and precipitation reactions, and validated against the porosity changes observed in the column experiment. Fluid transport is usually modelled by a one-dimensional equation of the advection-dispersion process. The use of dynamic column experiment (transport process) allows the simulation of systems, in which the alkaline fluid flows through porous solid media under a steady-state flow regime. It also permits reactive transport to be studied for either saturated or unsaturated soil. This study also focused on the effect of variable porosity, reactive surface area and pore volume on the alteration of the host rock, compared to fixed values of the same properties. The output from this modelling is then discussed for the near-field impacts anticipated at a deep geological repository.

\section{Column Experiment Design}

The model developed in this study was validated against the results of the BGS column experiment (Small et al. 2016), which was conducted as part of the Biogeochemical Gradients and Radionuclide Transport (BIGRAD, NE/H006464/1) project funded by the Natural Environment Research Council (NERC). The experiment consisted of a PEEK (Polyether ether ketone) columns packed with crushed sandstone (see Fig. 1; (Small et al. 2016). A solution representative of young cement leachate $\left(\mathrm{pH} 13.1\right.$ at $\left.25^{\circ} \mathrm{C}\right)$ was pumped through the columns. 


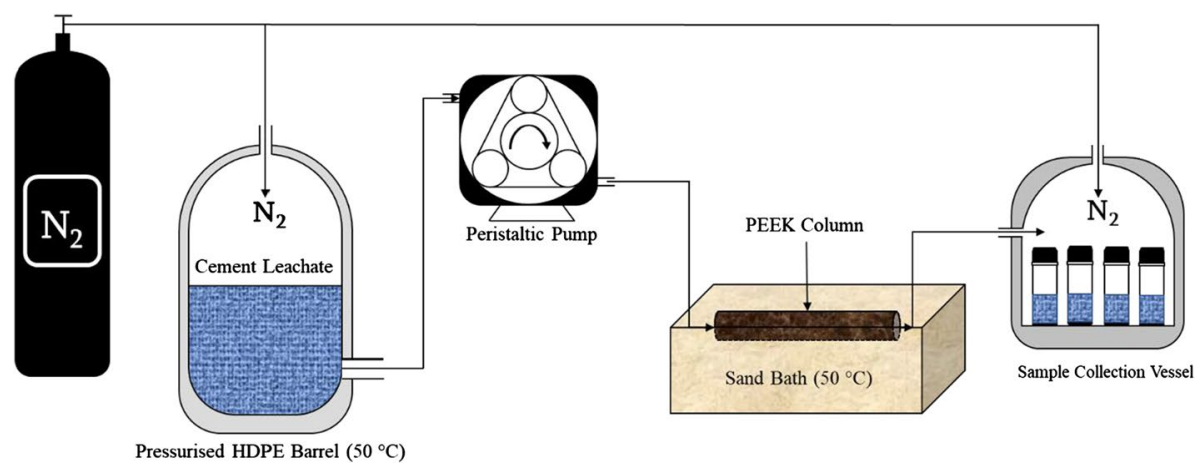

Fig. 1 Schematic of the BGS column experiment

\subsection{Crushed Sandstone}

The crushed sandstone used in the packed columns was Hollington sandstone from the Triassic Bromsgrove formation in the UK Midlands (Small et al. 2016). The sandstone was initially disaggregated, sieved through a $500 \mu \mathrm{m}$ nylon mesh, homogenised in a rotary blender and packed into the PEEK columns (7.5 mm diameter and $300 \mathrm{~mm}$ long). Table 1 shows the composition and proportion of minerals in the sandstone sample (Chen et al. 2015), determined by a combination of backscattered scanning electron microscopy, energy-dispersive X-ray microanalysis, microchemical mapping and petrographically image analysis.

After packing, the columns were first saturated by 37 pore volumes (PV) of demineralised water (produced by reverse osmosis followed by filtration and UV sterilisation). Next, 413 PV of the synthetic young cement leachate (YCL) was pumped though the column (composition reported in Table 2). The YCL was prepared with boiled, $\mathrm{N}_{2}$-sparged, deionised water and was kept in $25-\mathrm{L} \mathrm{N}_{2}$ over-pressured container to avoid carbonation reactions and a reduction in the leachate $\mathrm{pH}$.

Table 1 Mineralogical composition of Hollington sandstone (Chen et al. 2015)

\begin{tabular}{ll}
\hline Mineral & $\begin{array}{l}\text { Mineral propor- } \\
\text { tion (Volume } \\
\%)\end{array}$ \\
\hline Quartz & 75.5 \\
K-feldspar & 16 \\
Kaolinite & 3.5 \\
Illite/chlorite/smectite & 3.7 \\
Muscovite & 0.7 \\
Phlogopite & 0.2 \\
Apatite & 0.2 \\
TiO 2 & 0.3 \\
\hline
\end{tabular}


Table 2 Chemical composition of the synthetic young cement leachate (YCL) used in the British Geological Survey column experiment (Small et al. 2016)

\begin{tabular}{ll}
\hline Composition & YCL $(\mathrm{mg} / \mathrm{L})$ \\
\hline $\mathrm{Al}^{3+}$ & - \\
$\mathrm{Ca}^{2+}$ & 23 \\
$\mathrm{~K}^{+}$ & 3202 \\
$\mathrm{Mg}^{2+}$ & $0.07-$ \\
$\mathrm{Na}^{+}$ & 2178 \\
$\mathrm{Si}^{4+}$ & - \\
$\mathrm{OH}^{-}$ & $3192^{*}$ \\
$\mathrm{Measured} \mathrm{pH}^{+}$ & 13.1 at $25^{\circ} \mathrm{C}$ \\
& $(12.4$ at 50 \\
& $\left.{ }^{\circ} \mathrm{C}\right)$ \\
\hline
\end{tabular}

*Calculated by assuming charge balance with cations. Equivalent to $\mathrm{pH} 12.4$ at $50{ }^{\circ} \mathrm{C}$

\subsection{Column Operation and Sampling}

The column was placed in a $50{ }^{\circ} \mathrm{C}$ sand bath and connected to a $25-\mathrm{L}$ reservoir containing synthetic YCL. The reservoirs were heated to the experimental temperature of $50{ }^{\circ} \mathrm{C}$, and their headspace pressurised with $\mathrm{N}_{2}$ to prevent $\mathrm{CO}_{2}$ from entering the system (one atmosphere overpressure). A constant flux of YCL $(0.6 \mathrm{~mL} / \mathrm{h})$ was passed through the column for 233 days using peristaltic pumps. Column effluents were collected under an $\mathrm{N}_{2}$ atmosphere to minimise their exposure to atmospheric $\mathrm{CO}_{2}$. Table 3 summarises the initial experimental parameters.

Column effluent samples were collected within an $\mathrm{N}_{2}$-flushed chamber using individual plastic (PPE) bottles. All collected solutions were filtered using $0.2 \mu \mathrm{m}$ syringe PTFE (Acrodisc $^{\mathrm{TM}}$ ) filters and then sub-sampled to determine $\mathrm{pH}$, cations and anions. The $\mathrm{pH}$ of a subsample was determined immediately using a combination electrode, calibrated at $\mathrm{pH} 7,10,13$ and accurate to $\pm 0.02 \mathrm{pH}$ units. Sub-samples for cation analysis $(4 \mathrm{~mL})$ were diluted twofold with $18 \mathrm{M} \Omega$ demineralised water and then acidified with concentrated $\mathrm{HNO}_{3}(1 \% \mathrm{v} / \mathrm{v})$ to preserve the sample. Cation analysis was carried out using a combination of ICP-OES (inductively coupled plasma-optical emission spectrometry) and ICP-MS (inductively coupled plasma-mass spectrometry). A second undiluted sub-sample was taken for the determination of anions by IC (ion chromatography). All fluid samples were stored at $<5{ }^{\circ} \mathrm{C}$ until required for analysis.

\subsection{Tracer Test}

Independent tracer tests on the unreacted sandstone were carried out on duplicate columns to estimate the initial porosity using $0.1 \mathrm{~mol} \mathrm{dm}^{-3} \mathrm{NaClO}_{4}$ at $\mathrm{pH} 6.5$ as the permeant solution (the specific activity of the $\mathrm{HTO}, \mathrm{C}_{0}$ was approximately $17 \mathrm{~Bq} \mathrm{~cm}^{-3}$ ). The tritiated solution

Table 3 Initial experimental parameters

\begin{tabular}{llll}
\hline Initial porosity & Initial wet weight $(\mathrm{g})$ & Weight of rock $(\mathrm{g})$ & Pore volume $(\mathrm{mL})$ \\
\hline $42.7 \%$ & 110.756 & 21.249 & 5.97 \\
\hline
\end{tabular}


was injected continuously into the column, and when the specific activity at the outlet reached a steady state, the injected fluid was swapped to the tracer-free solution, and the elution profile was also recorded. The HTO tracer tests were repeated at the end of the column experiment when the HTO was added to the YCL. The specific activity of solutions was determined by liquid scintillation analysis (2100 TR, Packard, Canberra, Australia), measuring the energy range between 1 and $18.6 \mathrm{keV}$ and liquid scintillation cocktail Gold Star (Meridian, UK). No chemiluminescence was observed for the alkaline solutions; therefore, no neutralisation of the samples was required before measurements. The porosity of initial column samples was also estimated from the initial dry and wet weights of the column. The values from both methods were in agreement within $\pm 2 \%$ of volume.

\section{Modelling Approach}

PHREEQC (version 3.6.1) (Parkhurst and Appelo 2013) was used to perform all the thermodynamic and kinetic simulations. The code can perform a wide range of complex geochemical calculations between aqueous, gas and mineral dissolution/precipitation, along with surface complexion and ion exchange. The LLNL thermochemical database was used to describe the high-pH cement leachate/host rock system (Delany and Lundeen 1990). However, this database does not contain an adequate description of the dissolution/precipitation kinetics of $\mathrm{C}-\mathrm{S}-\mathrm{H}$ and $\mathrm{C}-\mathrm{A}-\mathrm{S}-\mathrm{H}$ phases (e.g. specific kinetic rate, reactive surface areas, etc.). Therefore, a hybrid kinetic equilibrium approach was implemented based on the mixing cell concept, which overcomes this shortcoming (Chen and Thornton 2018; Van der Lee 1998; Bethke 1996).

\subsection{Transport Process}

Flow was modelled in one-dimensional (1D), with inflow at one end and outflow at the other. It was modelled by subdividing the column into ten cells of equal length $(30 \mathrm{~mm}$ each, Fig. 2). The simulation was performed for a series of time steps in which each step represents the necessary time for the pore volume to move through each cell. The advection-dispersion transport process was simulated by moving the pore solution cell by cell along the column in a series of time steps. For the first and last cell, a flux-type boundary condition was chosen, in which the dispersion step follows the advection step. The extended form of Darcy's law was used to govern the movement of the solution flux through the flow path of the 1D saturated column, as below (Nardi et al. 2014):

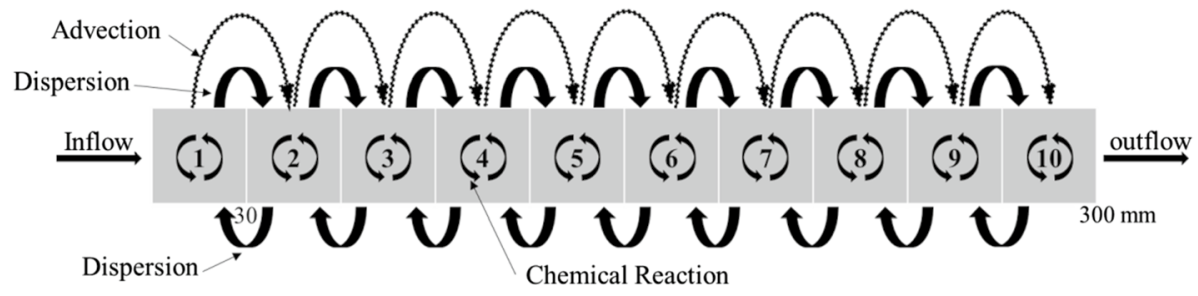

Fig. 2 Transport modelling concept 


$$
q_{l}=-\frac{\kappa}{\mu_{l}}\left(\nabla p_{l}-\rho_{l} g\right)
$$

where $q_{l}$ is the Darcy flux $\left(\mathrm{m}^{3} \mathrm{~m}^{-2} \mathrm{~s}^{-1}\right)$ for the liquid, $\kappa$ is permeability tensor $\left(\mathrm{m}^{2}\right), \mu_{l}$ is liquid dynamic viscosity $(\mathrm{Pa} \mathrm{s}), p_{l}$ is fluid pressure $(\mathrm{Pa}), \rho_{l}$ is liquid density $\left(\mathrm{Kg} \mathrm{m}^{-3}\right)$ and $g$ is gravity vector $\left(\mathrm{m} \mathrm{s}^{-2}\right)$. The advection-reaction-dispersion for the chemicals can be described as:

$$
\frac{\partial C_{i}}{\partial t}=-q_{l} \frac{\partial C_{i}}{\partial x}+D_{L} \underset{\begin{array}{c}
\text { Advection } \\
\text { Dispersion }
\end{array}}{\frac{\partial^{2} C_{i}}{\partial x^{2}}}-\sum_{m=1}^{n} v_{i m} R_{m}
$$

where $C_{i}$ is the total concentration of component $i$ in water $\left(\mathrm{mol} \mathrm{Kgw}^{-1}\right), t$ is time (s), $x$ is the distance $(\mathrm{m}), D_{L}$ is hydrodynamic dispersion coefficient $\left(\mathrm{m}^{2} \mathrm{~s}^{-1}\right), v_{i m}$ is the stoichiometric coefficient of component $i$ in kinetic reactant $m$ (dimensionless), $R_{m}$ is the overall dissolution/precipitation rate of kinetic reactant $m\left(\mathrm{~mol} \mathrm{Kgw}^{-1} \mathrm{~s}^{-1}\right)$ and $n$ is the number of kinetic reactants. Equation (2) is solved by an explicit finite difference algorithm for each time step using a split operator scheme, where the chemical interaction term $\left(v_{i m} R_{m}\right)$ for each mineral is calculated separately after the advection step and after the dispersion step for all equilibrium and kinetic reactions (Fig. 2). Consequently, the number of moles for pure phases, kinetic reactants and solid solution composition are updated in each cell.

\subsection{Kinetic Modelling of Dissolution and Precipitation Rates}

Dissolution of quartz, k-feldspar and kaolinite were modelled kinetically. The first two were included in the geochemical modelling because they were the dominant primary minerals in Hollington sandstone ( $>91 \%$ by volume). Kaolinite was included because it could potentially affect the evolution of the pore solution chemistry due to its high dissolution rate (Carroll and Walther 1990; Bauer and Berger 1998). The remaining minor phases (illite, muscovite, etc.) in Hollington sandstone were excluded from the model.

The rate of each mineral dissolution/precipitation reaction is calculated using Eq. (3), which assumes the rate is proportional to the normalised surface area and degree of disequilibrium (Appelo and Postma 2005):

$$
R_{i}=k_{i}\left(\frac{A_{i}}{V}\right)\left(\frac{M_{i}}{M_{i 0}}\right)^{n}\left(1-\left(\frac{I A P}{K}\right)_{i}\right) \text { foreachminerali }
$$

where $R$ is the overall dissolution/precipitation rate $\left(\mathrm{mol} \mathrm{L}^{-1} \mathrm{~s}^{-1}\right), k$ is the specific dissolution/precipitation rate $\left(\mathrm{mol} \mathrm{m} \mathrm{m}^{-2} \mathrm{~s}^{-1}\right), A$ is the effective surface area of the mineral $\left(\mathrm{m}^{2} \mathrm{~g}^{-1}\right)$, $V$ is the pore volume $(\mathrm{L}), M$ is the moles of solid at a given time, $M_{O}$ is the initial moles of solid and $(I A P / K)$ is equal to the saturation ratio $(S R)$ value of the mineral where IAP is the ion activity product and $K$ is the equilibrium constant. In the above equation, the molar concentration $\left(M / M_{0}\right)$ has $n$ power, which is a function of the initial crystal grain size distribution that affects the solid dissolution rate. Usually, a value of $2 / 3$ is used for uniformly dissolved cubes or spheres of the monodisperse population (Appelo and Postma, 2005). The term (1-SR) ensures that the rate of dissolution is highest when the system is far from equilibrium but tends to zero as equilibrium is approached. It also allows the rate equation to be applied for both super-saturation and undersaturation states, while the rate approaches zero (Equilibrium) as $I A P / K$ approaches one. 
Table 4 Temperature factors used to calculate silicate weathering rate $\mathrm{k}_{\mathrm{i}}$, at temperatures $(\mathrm{T} \mathrm{K})$ other than 8 ${ }^{\circ} \mathrm{C}(281 \mathrm{~K})$

\begin{tabular}{lllll}
\hline & $p k_{\mathrm{H}}$ & $p k_{\mathrm{H}_{2} \mathrm{O}}$ & $p k_{\mathrm{OH}}$ & $p k_{\mathrm{CO}_{2}}$ \\
\hline$p k_{i, 281}($ K-feldspar $)$ & 11.7 & 14.5 & 13.1 & 13 \\
$\frac{E_{a}}{2.303 R}$ & 3500 & 2000 & 2500 & 2000 \\
\hline
\end{tabular}

Table 5 Kinetic modelling approach and parameters for the primary minerals in Hollington sandstone rock

\begin{tabular}{llll}
\hline Mineral & Modelling approach & Surface area $\left(\mathrm{m}^{2} / \mathrm{g}\right)$ & Rate constant at $\left(\right.$ at $\left.50^{\circ} \mathrm{C}\right)\left(\mathrm{mol} \mathrm{m}^{-2} \mathrm{~s}^{-1}\right)$ \\
\hline Quartz & Kinetic & 0.02 (De Windt et al. 2008) & $\mathrm{k}=1 \times 10^{-12.7}$ (Knauss and Wolery 1988) \\
K-feldspar & Kinetic & 0.02 (De Windt et al. 2008) & $\mathrm{k}=7.26 \times 10^{-13}$ (Appelo and Postma, 2005) \\
Kaolinite & Kinetic & 20 (Klajmon et al. 2017) & $\mathrm{k}=1 \times 10^{-12.5}$ (Carroll and Walther 1990) \\
\hline
\end{tabular}

Along with the kinetic rates and reactive surface areas used for each mineral in the model, the unit of the effective surface area $A$ in Eq. (3) is $\left(\mathrm{m}^{2} \mathrm{~g}^{-1}\right)$. This correlates the surface area with the solid amount of minerals as the YCL-mineral reaction proceeds. Therefore, the initial mass of each mineral was included in Eq. (3) and the value was updated in each iteration to account for the changes in mass; otherwise, the dissolution/precipitation rate will be per unit mass for each mineral. Moreover, during the geochemical reaction, the dissolution/precipitation process will continue to change the mass of each mineral and hence the volume of the pore fluid. Consequently, the effective surface area in $\left(\mathrm{m}^{2}\right)$ for each mineral $i$ can be described as:

$$
A_{i}=A_{0} m_{t} X_{i} \text { for each minerali }
$$

where $m_{t}$ is the total mass of the rock sample, $A_{0}$ is the initial surface area and $X_{i}$ is the mass fraction of each mineral in the rock sample (Beckingham et al. 2016).

The values of the specific dissolution rate, $k$, for silicate minerals undergoing weathering are highly dependent on temperature (Worley 1994, Appelo and Postma 2005). Therefore, published $\mathrm{k}$ values for $\mathrm{k}$-feldspar dissolution at $281 \mathrm{~K}$ were corrected for temperature (see Table 4). The value of $k$ for quartz and kaolinite was taken from the experimental literature (Knauss and Wolery 1988; Carroll and Walther 1990). The kinetic information from the literature used for the minerals in Hollington sandstone is summarised in Table 5, along with the rates and reactive surface areas used for each mineral in the model.

$$
p k_{i, T}=-\log k_{i, T}=p k_{i, 281}+\frac{E_{a}}{2.303 R}\left[\frac{1}{T}-\frac{1}{281}\right]
$$

The equation below then calculates the specific dissolution rate:

$$
k=k_{\mathrm{H}^{+}} \frac{\left[\mathrm{H}^{+}\right]^{n}}{f_{\mathrm{H}}}+k_{\mathrm{H}_{2} \mathrm{O}} \frac{1}{f_{\mathrm{H}_{2} \mathrm{O}}}+k_{\mathrm{OH}^{-}} \frac{\left[\mathrm{OH}^{-}\right]^{o}}{f_{\mathrm{OH}}}+k_{\mathrm{CO}_{2}} \frac{\left[\mathrm{P}_{\mathrm{CO}_{2}}\right]^{0.6}}{f_{\mathrm{CO}_{2}}}
$$

where $k$ is the specific dissolution/precipitation rate $\left(\mathrm{mol} \mathrm{m}^{-2} \mathrm{~s}^{-1}\right), \boldsymbol{k}_{\boldsymbol{H}^{+}}, \boldsymbol{k}_{\boldsymbol{H}_{2} \boldsymbol{O}}, \boldsymbol{k}_{\boldsymbol{O H}^{-}}, \boldsymbol{k}_{\boldsymbol{C O}_{2}}$ are solute rate coefficients $\left(\mathrm{mol} \mathrm{m} \mathrm{m}^{-2} \mathrm{~s}^{-1}\right.$ ), and $\boldsymbol{f}_{\boldsymbol{H}}, \boldsymbol{f}_{\mathrm{H}_{2} \boldsymbol{O}}, \boldsymbol{f}_{\boldsymbol{O H}}, \boldsymbol{f}_{\mathrm{CO}_{2}}$ are inhibition factors. $n$ and $o$ are constant values, which for k-feldspar are equal to 0.5 and 0.3 , respectively (Appelo and Postma,2005). 


$$
\begin{gathered}
f_{H}=\left[1+\frac{[B C]}{\operatorname{Lim}_{B C, H}}\right]^{x_{B C}}\left[1+\frac{\left[A l^{3+}\right]}{\operatorname{Lim}_{A l, H}}\right]^{x_{A l}} \\
f_{\mathrm{H}_{2} \mathrm{O}}=\left[1+\frac{[B C]}{\operatorname{Lim}_{B C, \mathrm{H}_{2} \mathrm{O}}}\right]^{z_{B C}}\left[1+\frac{\left[A l^{3+}\right]}{\operatorname{Lim}_{\mathrm{Al}, \mathrm{H}_{2} \mathrm{O}}}\right]^{z_{A l}} \\
f_{\mathrm{OH}}=f_{\mathrm{CO}_{2}}=1
\end{gathered}
$$

where Lim is the limiting activity, [BC] indicates the sum of the base cations $\mathrm{Na}^{+}, \mathrm{K}^{+}, \mathrm{Mg}^{+}$ and $\mathrm{Ca}^{+}$activities, and $x_{i}$ and $z_{i}$ are empirical values as given in Table 6 .

\subsection{Secondary Phases}

The overall reaction for the evolution of hyper-alkaline cement leachate is well known (Glasser 2001; Harris et al. 2001a, 2001b; Gaucher and Blanc 2006; Helinski et al. 2007). Generally, after hydration of the cement materials, high-sodium and high-potassium alkali leachate will break through, followed by the dissolution of portlandite and progression of calcium that forms $\mathrm{C}-\mathrm{S}-\mathrm{H}$ gels and high-Ca/Si-ratio minerals. Due to the composition of Hollington sandstone and the hyper-alkalinity of YCL, the major secondary minerals that are likely to form are $\mathrm{C}-\mathrm{S}-\mathrm{H}, \mathrm{C}-\mathrm{A}-\mathrm{S}-\mathrm{H}$ and zeolite minerals phases (Chen et al. 2015). The $\mathrm{C}-\mathrm{S}-\mathrm{H}$ phases were represented in this study by $\mathrm{C}-\mathrm{S}-\mathrm{H}$ gel and tobermorite-14A, which is the most evolved $\mathrm{C}-\mathrm{S}-\mathrm{H}$ mineral that forms from C-S-H gel (Bethke 1996). In terms of aluminosilicate minerals, prehnite and saponite$\mathrm{Mg}$ were selected as an analogue for the hydrated silicate and clay phases, respectively. Saponite is usually represented in thermodynamic models as an $(\mathrm{Na}, \mathrm{Mg}, \mathrm{Ca}, \mathrm{K})$-bearing aluminosilicate and will act as a potential sink for $\mathrm{Mg}$. Conversely, prehnite has been identified as a possible precipitated secondary phase from previous geochemical modelling of cement leachate-host rock interactions (Rose 1991; Pfingsten et al. 2006; Gysi and Stefánsson 2012). At the same time, the high sodium-calcium ratio of the cementitious porewater favours the formation of aluminous zeolites, such as laumontite, analcime, mesolite and mordenite minerals (Walker 1960; Savage et al. 1987; De Windt et al. 2008; Idiart et al. 2020). Therefore, those phases, together with phillipsite, were selected as potential $\mathrm{Ca} / \mathrm{Na} / \mathrm{K}$-bearing zeolites which will remove $\mathrm{Na}$ and $\mathrm{K}$ from the pore fluid if they precipitate. The last mineral included in the simulation was hydrogarnet, a calcium aluminate phase that is usually formed with the $\mathrm{C}-\mathrm{S}-\mathrm{H}$ gel and included in the modelling of cement alternation reactions (Chaparro et al. 2017; Wilson et al. 2017 , 2018). This mineral is most likely to form in the presence of a high $\mathrm{Ca} /(\mathrm{Al}+\mathrm{Si})$

Table 6 Values of empirical exponents and limiting activity in the equation of $f_{\mathrm{H}}$ and $f_{\mathrm{H}_{2} \mathrm{O}}$ (Appelo and Postma 2005)

\begin{tabular}{llllll}
\hline$x_{B C}$ & $x_{A l}$ & $z_{B C}$ & $z_{A l}$ & $\lim _{A l}$ & $\lim _{B C}$ \\
\hline 0.15 & 0.4 & 0.15 & 0.14 & $4 \mathrm{e}^{-6}$ & $5 \mathrm{e}^{-4}$ \\
\hline
\end{tabular}


Table 7 Secondary minerals included in the model using an equilibrium approach. Data from LLNL thermochemical database (Delany and Lundeen 1990)

\begin{tabular}{llc}
\hline Mineral & Structural formula & $\begin{array}{c}\text { Rate constant at (at } \\
\left.50{ }^{\circ} \mathrm{C}\right)\left(\mathrm{mol} \mathrm{m}^{-2} \mathrm{~s}^{-1}\right)\end{array}$ \\
\hline$C-S-H$ & & \\
C-S-H gel & $\mathrm{Ca}_{5} \mathrm{Si}_{6} \mathrm{H}_{21} \mathrm{O}_{27.5}$ & 60.84 \\
Tobermorite-14A & $\mathrm{Ca}_{5} \mathrm{Si}_{6} \mathrm{H}_{21} \mathrm{O}_{27.5}$ & 63.84 \\
Zeolite & & \\
Analcime & $\mathrm{NaAlSi}_{2} \mathrm{O}_{6}: \mathrm{H}_{2} \mathrm{O}$ & 6.13 \\
Laumontite & $\mathrm{CaAl}_{2} \mathrm{Si}_{4} \mathrm{O}_{12}: 4 \mathrm{H}_{2} \mathrm{O}$ & 13.66 \\
Mesolite & $\mathrm{Na}_{2} \mathrm{Ca}_{2}\left(\mathrm{Al}_{2} \mathrm{Si}_{3} \mathrm{O}_{10}\right) 3: 8 \mathrm{H} 2 \mathrm{O}$ & 13.61 \\
Phillipsite & $\mathrm{K}_{2.8} \mathrm{Na}_{3.2} \mathrm{Ca}_{0.8} \mathrm{Al}_{7.6} \mathrm{Si}_{24.4} \mathrm{O}_{64}: 24 \mathrm{H}_{2} \mathrm{O}$ & 6.65 \\
Mordenite & $\mathrm{Ca}_{2 .} \mathrm{Na}_{36} \mathrm{Al}_{.94} \mathrm{Si}_{5.06} \mathrm{O}_{12}: 3.4 \mathrm{H}_{2} \mathrm{O}$ & -5.19 \\
Others & & \\
Prehnite & $\mathrm{Ca}_{2} \mathrm{Al}_{2} \mathrm{Si}_{3} \mathrm{O}_{10}(\mathrm{OH})_{2}$ & 32.93 \\
Saponite-Mg & $\mathrm{Mg}_{3.165} \mathrm{Al}_{33} \mathrm{Si}_{3.67} \mathrm{O}_{10}(\mathrm{OH})_{2}$ & 26.25 \\
Hydrogarnet & $\mathrm{Ca}_{3} \mathrm{Al}_{2}(\mathrm{OH})_{12}$ & 82.28 \\
\hline
\end{tabular}

ratio and at high temperature (Nakahira et al. 2008; Vasconcelos et al. 2018). Also, in case the dissolution of portlandite was high, hydrogarnet will be altered to Friedel's salt once reacted with $\mathrm{Ca}(\mathrm{OH})_{2}$, which will result in an increase in $\mathrm{pH}$ (Wilson et al. 2017, 2018). It is noteworthy that the precipitation and potential dissolution of the secondary minerals formed as a result of the primary mineral weathering was modelled using the equilibrium approach (Table 7).

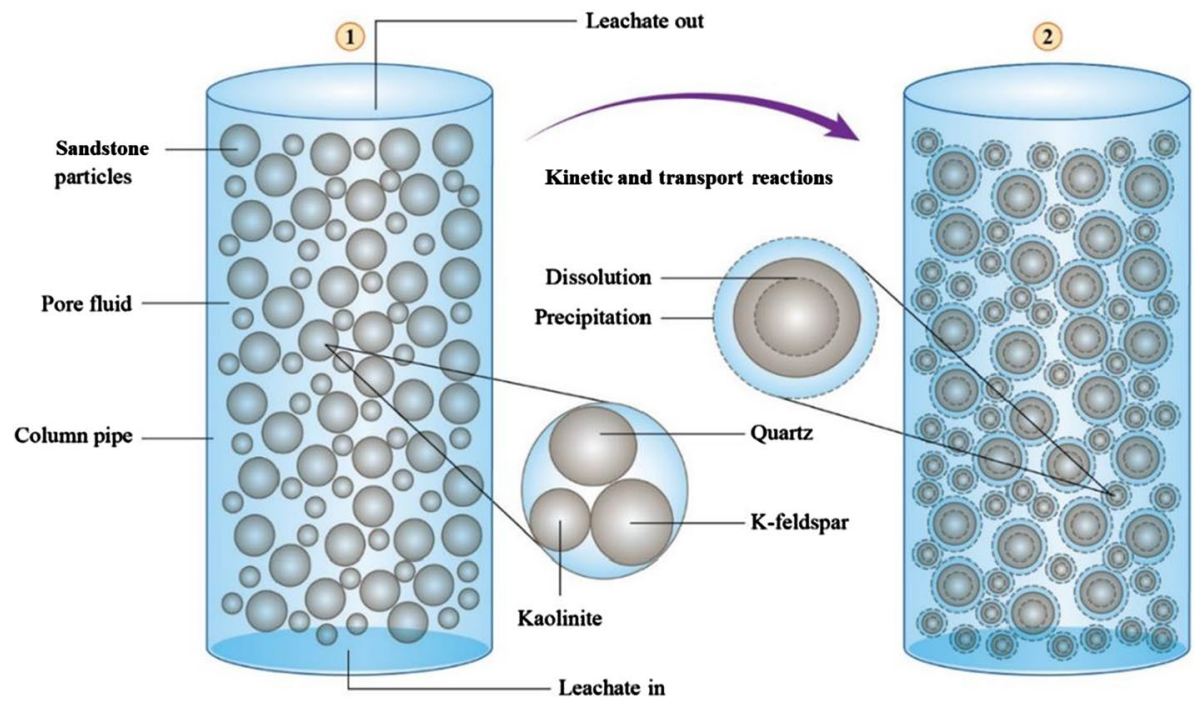

Fig. 3 Porosity evolution concept 


\subsection{Variable Porosity Calculation}

The overall system in Fig. 3 shows a water-saturated structure with the effect of transport and kinetic dissolution/precipitation processes on the mineral surface area and pore volume.

The whole system can be described by the equation of conservation of volume as:

$$
\begin{gathered}
V_{\text {system }}^{t=0}=V_{\text {system }}^{t} \\
V_{\text {Pore }}^{t=0}+V_{\text {Solid }}^{t=0}=V_{\text {Pore }}^{t}+V_{\text {Solid }}^{t}
\end{gathered}
$$

Rearranging Eq. (10) leads to

$$
V_{\text {Pore }}^{t}=V_{\text {Pore }}^{t=0}+V_{\text {Solid }}^{t=0}-V_{\text {Solid }}^{t}
$$

where $V_{\text {pore }}$ and $V_{\text {solid }}$ are the pore fluid and solid volume of all minerals in the rock sample. If both sides of Eq. (11) are divided by the total volume $V_{T}$, then

$$
\begin{gathered}
\phi_{t}=\phi_{t=0}+\frac{V_{\text {Solid }}^{t=0}}{V_{T}}-\frac{V_{\text {Solid }}^{t}}{V_{T}} \\
\Delta \phi_{t}=\phi_{t=0} \pm \sum\left(\frac{V_{\frac{\text { Diss }}{\text { prec }} \text { mole }, t}}{V_{T}}\right)
\end{gathered}
$$

(Note : +for dissolving; - for precipitating)

$$
\Rightarrow \Delta \phi_{t}=\phi_{t=0} \pm \sum\left(\frac{M V_{i} * M_{i, t}}{V_{T}}\right)
$$

(note : for each minerali)

where $\phi$ is the porosity, $M V$ is molar volume and $M$ is the number of moles. To link the evolved porosity with the mineral surface area (Eq. 4), a mathematical equation was developed as (Lichtner 1988):

$$
A_{r}^{t}=A_{r}^{t=0}\left(\frac{1-\phi_{t}}{1-\phi_{t=0}}\right)^{2 / 3}
$$

where $A_{r}^{t=0}$ is the reactive surface area of the mineral at the initial porosity. Along with the evolved surface area, the dissolution/precipitation process for each mineral will change its mass and hence the volume of the pore fluid.

$$
V_{\text {pore,total }}=V_{\text {Pore }}^{t=0} \pm \sum V_{\frac{\text { Diss }}{\text { prec }} \text { moles }, t}
$$

(Note : +for dissolving;-for precipitating) 


$$
m_{i, t}=m_{i, t=0} \pm m_{\frac{\text { Diss }}{\text { prec }} \text { moles }, t, i}
$$

(Note : -for dissolving;+for precipitating, for each minerali)

Ultimately, substituting Eq. 15 into Eq. 3, combined with the changes in mass and pore volume over time (Eqs. 16 and 17), leads to a new equation:

$$
R_{i}=\frac{k_{i}}{V_{t}}\left(A_{r, i}^{t=0}\left(\frac{1-\phi_{t}}{1-\phi_{t=0}}\right)^{2 / 3} m_{i, t}\right)\left(\frac{M}{M_{0}}\right)_{i}^{n}\left(1-\left(\frac{I A P}{K}\right)_{i}\right)
$$

(note : for each minerali)

\section{Results and Discussion}

The cement leachate composition at the outlet of the column was sampled regularly to assess changes in the fluid composition induced by precipitation of components in the leachate and/or dissolution of the primary phases in the sandstone. Figures 4-13 compare the experimental results and model simulations during the leachate transport through the column. The modelled $\mathrm{pH}$ and solute concentrations are compared against the experimental measurements. The concentration and saturation indices $(=\log (\mathrm{IAP} / \mathrm{Ksp})$ or $\log (\mathrm{SR}))$ of all significant elements involved in the evolution of geochemical reactions are plotted against time and cell numbers. Two types of analysis were performed and compared: one is the traditional fixed porosity, pore volume and reactive surface area method; and the other is the more complex model with variable porosity and reactive surface area developed in this study.

The modelled concentrations of $\mathrm{Na}$ and $\mathrm{K}$ are shown in Fig. 4. The simulated profiles agree well with the experimental results, as the chemistry of the injecting fluid mainly controls their concentrations, rather than dissolution and precipitation of primary and secondary minerals. The modelling shows that analcime was close to equilibrium, but instead the concentration of $\mathrm{Na}$ decreased slightly as this ion was removed by the precipitation of mesolite ( $\mathrm{Na}-\mathrm{Ca}$ zeolite, Fig. 5). The plots show that mesolite redissolved following
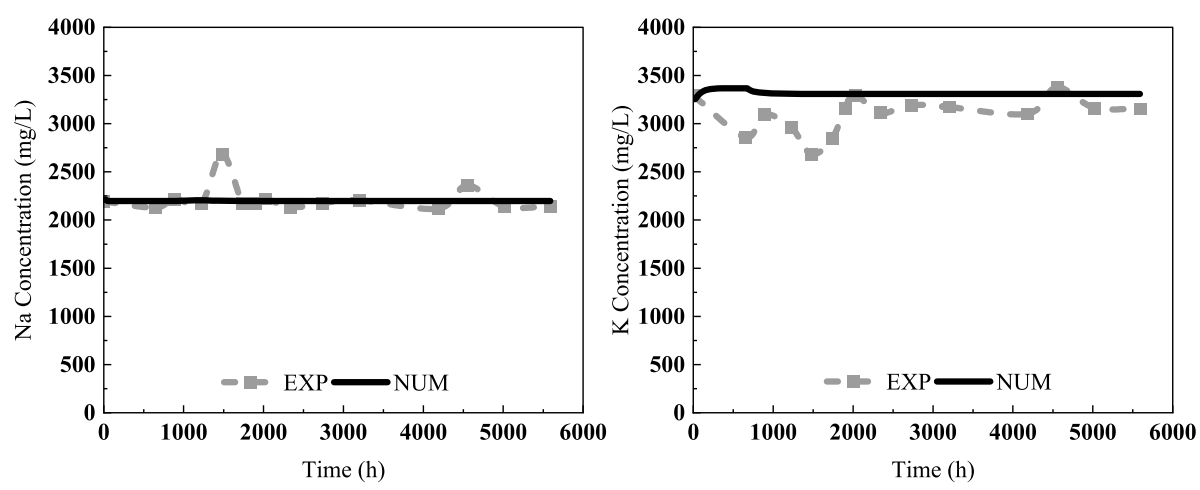

Fig. 4 Potassium and sodium ion concentrations versus time (for variable porosity model) 
Fig. 5 Saturation indices for analcime and mesolite versus time (for variable porosity model)

Fig. 6 Saturation indices for primary minerals versus time for both fixed and variable porosity models
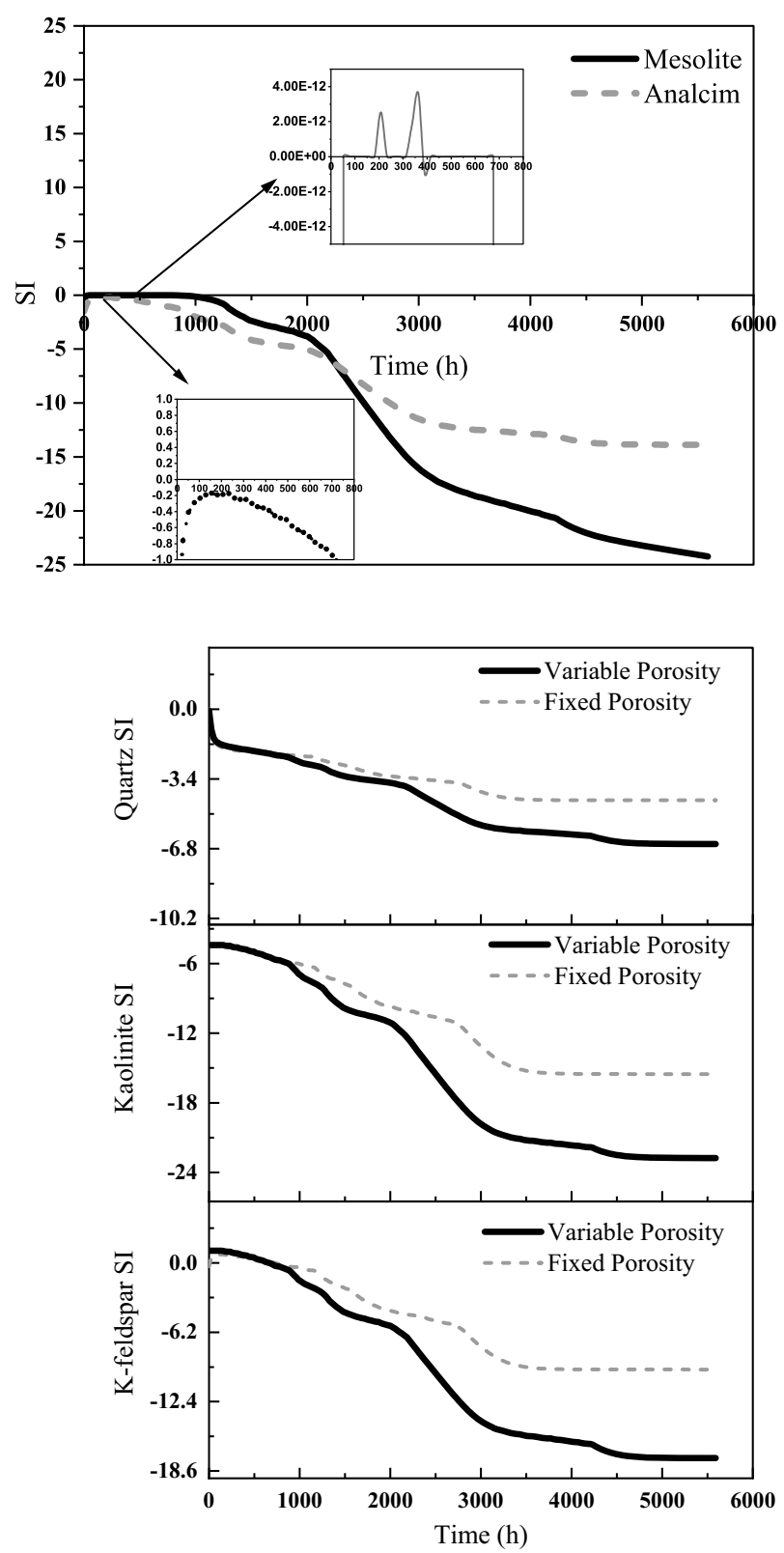

precipitation at an early stage of the experiment. Meanwhile, the initial high concentration of $\mathrm{K}$ ions reacts as a buffer for k-feldspar dissolution. This is also reflected in the saturation indices in Fig. 6, which shows that k-feldspar has a lower tendency for dissolution in the beginning and starts to dissolve later compared to quartz and kaolinite. Some studies have also suggested that the solubility of $\mathrm{k}$-feldspar can be decreased by high $\mathrm{pH}$ values (Brown et al., 2008). 
Quartz, kaolinite and k-feldspar dissolve as a result of varying degrees of reaction with the YCL. In Fig. 6, both quartz and kaolinite have a negative saturation index in both scenarios (fixed and variable porosity), which implies continuous dissolution throughout the experiment. This is related to the fact that the precipitation of secondary phases consumes ions in the cement leachate and those released from the dissolution of the primary minerals. Consequently, the precipitation of secondary minerals can help maintain conditions which are far from equilibrium, leading to faster dissolution rates. Conversely, k-feldspar is initially at equilibrium (For $500 \mathrm{~h}$ ) before it starts to dissolve. Comparing the saturation indices, all three minerals in the variable porosity model show a steeper decrease in values, with k-feldspar beginning to dissolve earlier in this model.

The initial fast reaction with the YCL will begin with the reaction of fine mineral particles on the grain surfaces, resulting in the rapid release of $\mathrm{Si}$ and $\mathrm{Al}$ ions into the solution.
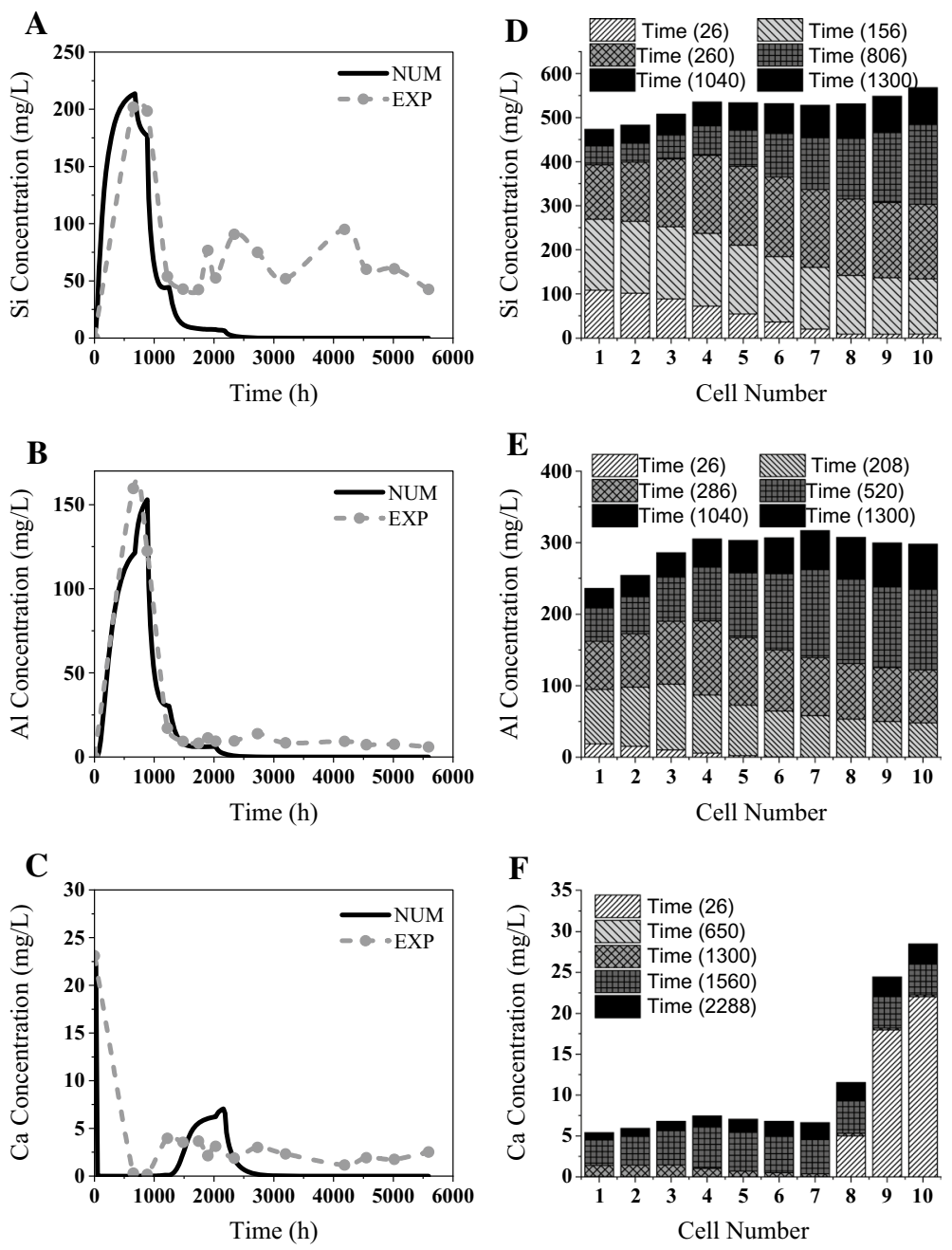

Fig. 7 Silicon, aluminium and calcium ion concentrations versus time (h) and along the ten cells for variable porosity model 
This was correlated in the analysis, as shown in Fig. 7 (Plot A and B). The trend and magnitude of $\mathrm{Si}$ and $\mathrm{Al}$ in plots $\mathrm{A}$ and $\mathrm{B}$ are reproduced well and are correlated with the experimental data, exhibiting similar changes in concentration behaviour. The values start with an initial rise in $\mathrm{Si}$ and $\mathrm{Al}$ concentrations until maximum values are reached, after which they were removed (accompanied by Ca consumption), and the concentrations decreased to a steady-state value. Despite a similar trend between the experimental and modelling results, the decrease in Si concentration (Plot A) is smaller in the experimental results. This could be related to the fact that some secondary phases will precipitate on the surfaces of the primary minerals, reducing the reactive surface area and the dissolution process. This will restrict the precipitation of the secondary phases and the removal of Si from the solution. In general, the reduction in the concentration of $\mathrm{Ca}$ (Fig. 7c), Si and Al were marked, mainly due to the formation of secondary C-S-H /C-A-S-H mineral phases with different $\mathrm{Ca} / \mathrm{Si}$ ratios (Savage et al. 1992, 2002, 2007, 2010; Pfingsten et al. 2006; Savage 2011) as shown by the saturation indices of $\mathrm{C}-\mathrm{S}-\mathrm{H}$ gel, tobermorite-14A, prehnite, saponite-Mg and mesolite (Fig. 8). This type of precipitation has also been observed in natural systems (Alexander et al. 1998; Pitty and Alexander 2010). After some time, the precipitated secondary phases will dissolve again, creating a slight increase in the Ca concentration observed in the later stage of the experiment (Fig. 7c).

The $\mathrm{Si}$ and $\mathrm{Al}$ curves in Fig. 7d and e show two different patterns of ion consumption. During the first $300 \mathrm{~h}$, the amount of $\mathrm{Si}$ and $\mathrm{Al}$ consumption is evenly balanced in all the cells, but with higher initial concentrations in the first five cells as a result of $\mathrm{Si}$ and $\mathrm{Al}$ release from the dissolution process. After reaching a peak (around $800 \mathrm{~h}$, plot A and B),
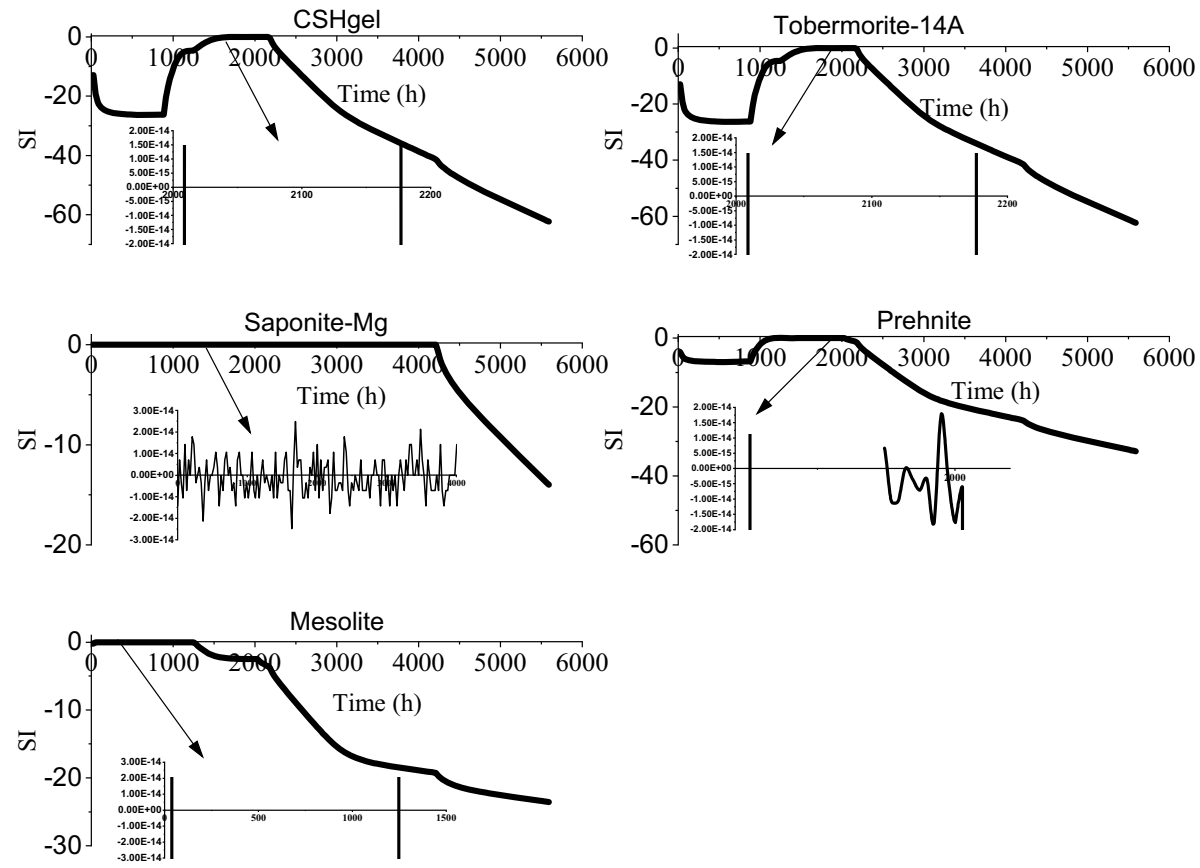

Fig. 8 Saturation indices for C-S-H-gel, tobermorite-14A, prehnite, saponite-Mg and mesolite versus time for variable porosity models 
the following time plots show the opposite behaviour as the precipitation of $\mathrm{C}-\mathrm{S}-\mathrm{H}$ and $\mathrm{C}-\mathrm{A}-\mathrm{S}-\mathrm{H}$ led to lower values of concentrations in the first 5 cells. The figures also indicate that the consumption of both ions is greatest in the first $1300 \mathrm{~h}$, which also represents the period during which $\mathrm{C}-\mathrm{S}-\mathrm{H} / \mathrm{C}-\mathrm{A}-\mathrm{S}-\mathrm{H}$ precipitate before starting to dissolve again (Fig. 8).

As the dissolution of the primary minerals (quartz, kaolinite and k-feldspar) did not release $\mathrm{Ca}$, the concentration of this ion was controlled by the initial chemical composition of the background solution. During the breakthrough of the injected hyper-alkaline solution, the high $\mathrm{Ca}$ concentration in the background solution will mostly be retarded due to the precipitation of secondary $\mathrm{C}-\mathrm{S}-\mathrm{H} / \mathrm{C}-\mathrm{A}-\mathrm{S}-\mathrm{H}$ phases once there were enough $\mathrm{Si}$ ions released from the dissolution of primary minerals. This will cause mineral precipitation towards the inlet of the column, which explain the higher values of $\mathrm{Ca}, \mathrm{Si}$ and $\mathrm{Al}$ at the end of the column (Fig. 7d, e and f). Moreover, the plot (7F) shows that the Ca concentration is removed within the seven cells and primarily in the first $26 \mathrm{~h}$. Later, from $1300 \mathrm{~h}$ the $\mathrm{Ca}$ concentration starts to increase again as $\mathrm{C}-\mathrm{S}-\mathrm{H} / \mathrm{C}-\mathrm{A}-\mathrm{S}-\mathrm{H}$ phases start to dissolve until complete dissolution around $2300 \mathrm{~h}$ (the same time when the saturation indices decrease to less than zero in Fig. 8).

Figure 8 shows the evolution of the saturation indices for $\mathrm{C}-\mathrm{S}-\mathrm{H}-\mathrm{gel}$, tobermorite-14A, prehnite, saponite-Mg and mesolite at different times in the experiment. The positive SI values indicate that the cement pore fluid is super-saturated with respect to those phases and hence thermodynamic precipitation may occur. Conversely, dissolution will occur when the SI is negative (under saturation). The simulation predicted that only those five minerals could potentially precipitate during the experiment. It should be noted that the lack of zeolite formation in the experiments could also be related to the experiment temperature, as some studies have observed zeolites precipitation only above $60{ }^{\circ} \mathrm{C}$ (Hodgkinson and Hughes 1999; Fernandez et al. 2012). Moreover, the kinetics of zeolite precipitation may be very slow, relative to the residence time in the column (i.e. there is a kinetic limitation even though the fluid chemistry supports precipitation). The number of dissolved/ precipitated moles for those secondary phases is presented in Fig. 9. It is noteworthy that in Eq. (3), if the mineral is precipitating, then the value of $(1-S R)$ will be negative and hence the number of moles. This is reasonable as it indicates that the mineral is being
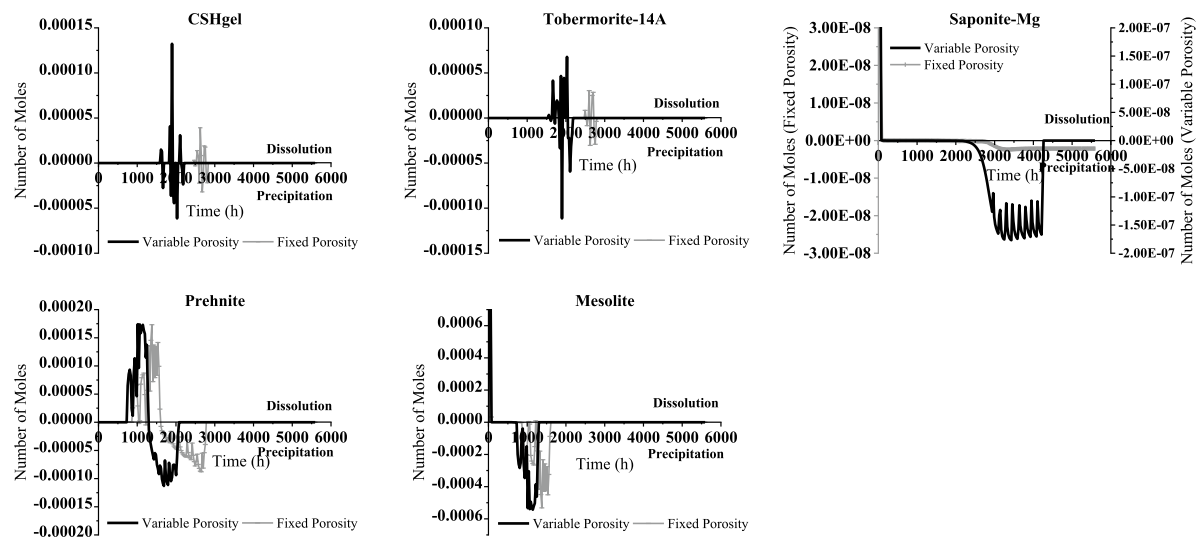

Fig. 9 Number of precipitated/dissolved moles for C-S-H-gel, tobermorite-14A, prehnite, saponite-Mg and mesolite versus time for variable porosity models 
removed from the solution. Consequently, the number of precipitated moles is represented by the lower side of the charts while the dissolved number of moles is in the upper side. In general, all five plots show that the zone of secondary mineral precipitation is displaced in the fixed porosity model. The number of precipitated moles is also higher in all five plots and especially for saponite-Mg, which shows a much higher degree of precipitation in the variable porosity model. Both findings agree well with the fact that in the variable porosity model, the ions will be released faster from the primary minerals because of the higher exposure between the minerals in the sandstone and the YCL. Hence, the precipitation cycle will start earlier as well.

The variable porosity model (Fig. 10) also demonstrates a better fit in ion concentration because it led to more reactive surface area with the YCL. The time to the peak point and the decreasing slope is a more realistic representation of the system since more ions were released to the synthetic leachate, resulting in greater precipitation. Figure 11 shows that as the dissolution process takes place, the volume of quartz and kaolinite decreases, and the porosity increases. While k-feldspar was initially precipitating, the plot shows two lines, one for precipitation (negative moles) and one for dissolution (positive moles). Both curves start with a high value of dissolved/precipitated moles and decrease along the column. Simultaneously, the volume of k-feldspar increases slightly in the beginning, accompanied the decrease in the k-feldspar porosity (this is also reflected in the saturation index plot, which shows slight precipitation at the initial hours, Fig. 6) until dissolution starts and the volume decreases. On the other hand, the number of moles released was highest from

Fig. 10 Silicon, aluminium and calcium ion concentrations versus time for both fixed and variable porosity models

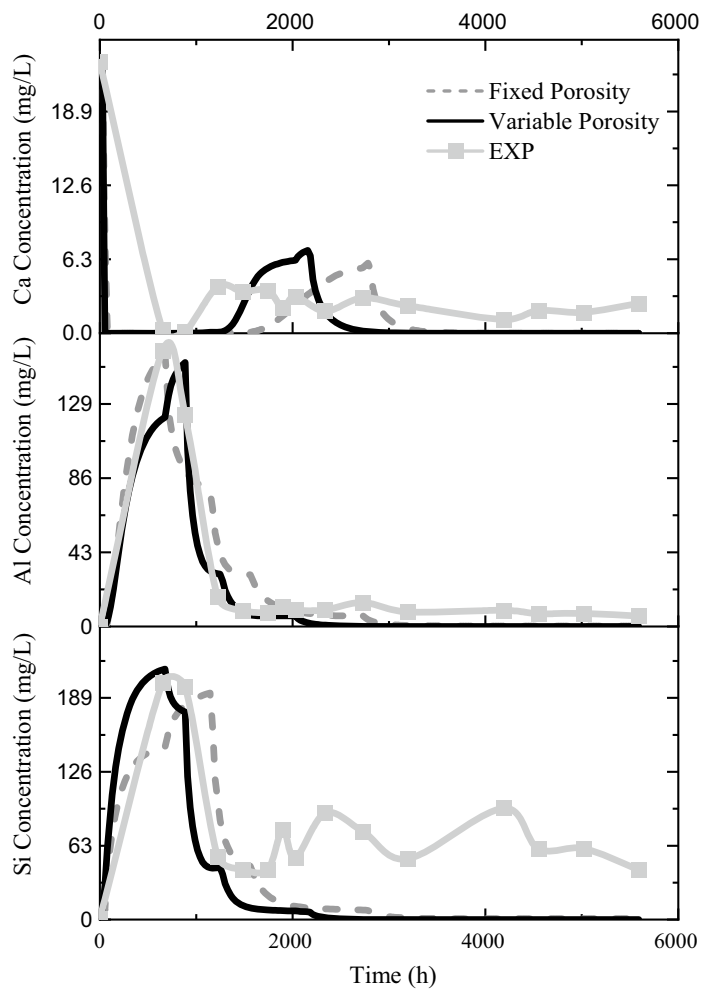



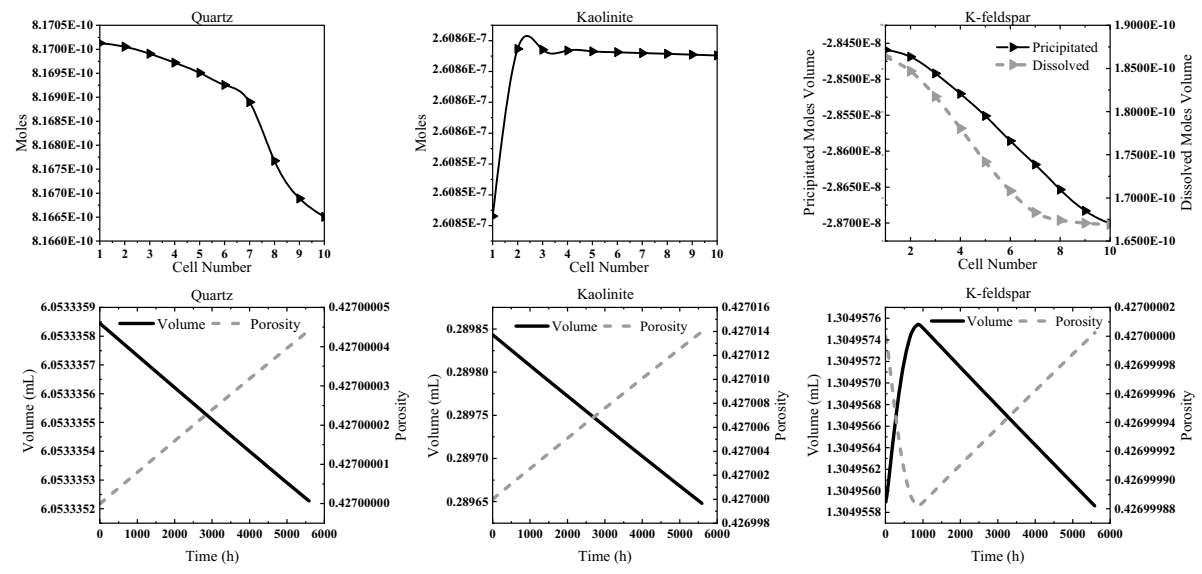

Fig. 11 Number of dissolve moles in each cell and porosity with volume changes per time for quartz, kaolinite and k-feldspar (for variable porosity model)
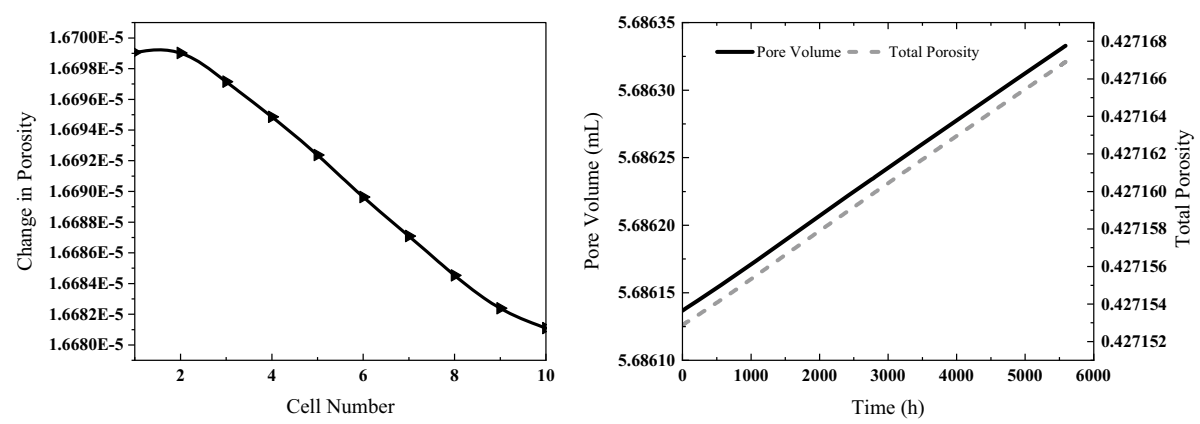

Fig. 12 Changes in total porosity and pore volume of the system (for variable porosity model)

kaolinite despite its low weight percentage, which indicates its high reaction rate with the YCL.

Figure 12 shows that an overall increase in the porosity and pore volume results from the decreased mineral volume, especially with no stable precipitation of secondary $\mathrm{C}-\mathrm{S}-\mathrm{H}$ or $\mathrm{C}-\mathrm{A}-\mathrm{S}-\mathrm{H}$ phases (redissolution, Fig. 8). The analysis also demonstrates that the change in porosity decreases towards the column outlet (increased cell numbers), similar to the dissolution process, except for the first cell, which has a slightly lower porosity value than the second. This may result from the higher precipitation of $\mathrm{C}-\mathrm{S}-\mathrm{H} / \mathrm{C}-\mathrm{A}-\mathrm{S}-\mathrm{H}$ phases close to the column flow inlet, as noticed in the experiment (Small et al. 2016). The pH value is usually a good indicator of the chemical evolution in geochemical systems. However, Fig. 13 shows that both experimental and simulated $\mathrm{pH}$ values are very similar and were not delayed significantly. This means that the studied system has not changed significantly in terms of mineral alternation. 
Fig. 13 Variation in injected leachate $\mathrm{pH}$ at $50{ }^{\circ} \mathrm{C}$ versus time (for variable porosity model)

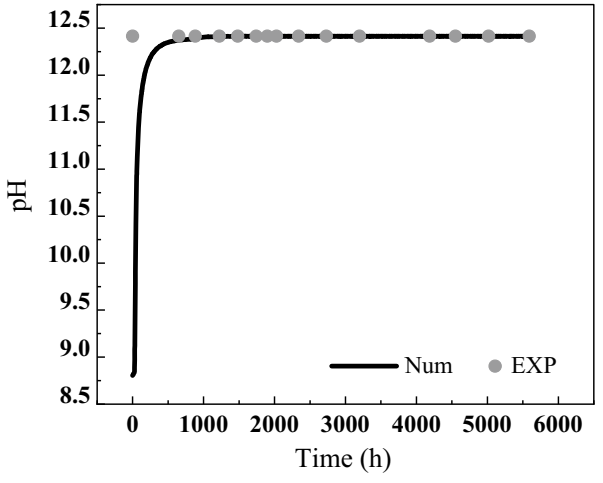

\section{Conclusion}

The geochemical modelling code PHREEQC was used to evaluate two different porosity, 1D transport, models for a column experiment in which the host rock mineralogy and geochemistry changes when exposed to a YCL. The column experiment was carried out to identify the dominant geochemical reactions and examine the effect of variable porosity, reactive surface area and pore volume on the geochemical alternation. The model captures the critical elements that describe the chemical evolution of the cement hyper-alkaline leachate during the dissolution of primary minerals and the precipitation of secondary $\mathrm{C}-\mathrm{S}-\mathrm{H}$ /C-A-S-H phases during migration through the sandstone. The experimental results are reproduced well by the model simulations, supporting the geochemical interpretation of the reactions which control the leachate chemistry, mineral transformations and porosity evolution of the sandstone. The modelled concentration profiles showed that decreases in $\mathrm{Ca}, \mathrm{Al}$ and $\mathrm{Si}$ concentrations were related to the formation of $\mathrm{C}-\mathrm{S}-\mathrm{H} / \mathrm{C}-\mathrm{A}-\mathrm{S}-\mathrm{H}$ and zeolite minerals as secondary phases (e.g. C-S-H-gels and mesolite). The overall porosity of the system increased in the simulation as a result of primary mineral dissolution and specifically in the absence of stable precipitation of the secondary $\mathrm{C}-\mathrm{S}-\mathrm{H} / \mathrm{C}-\mathrm{A}-\mathrm{S}-\mathrm{H}$ phases. The variable porosity model showed a better fit in terms of the ion concentration and precipitation of secondary phases, due to better exposure between the YCL and the minerals in the host sandstone. The work in this paper demonstrates the importance of modelling experimental studies, which with suitable analogues can develop confidence in simulating hyper-alkaline cement leachate transport in engineered barriers constructed for the containment of nuclear waste.

Acknowledgements The authors acknowledge financial support from NERC in the project BIogeochemical Gradients and RADionuclide transport (BIGRAD; Grant Reference NE/H006464/1) for the completion of this work. The first, fourth and fifth authors acknowledge Kuwait Petroleum Company (KPC) for sponsoring this work. The authors would like to acknowledge the edits and comments on early draft of this paper from Dr Simon Norris (Radioactive Waste Management Ltd., Harwell, U.K.).

Open Access This article is licensed under a Creative Commons Attribution 4.0 International License, which permits use, sharing, adaptation, distribution and reproduction in any medium or format, as long as you give appropriate credit to the original author(s) and the source, provide a link to the Creative Commons licence, and indicate if changes were made. The images or other third party material in this article are included in the article's Creative Commons licence, unless indicated otherwise in a credit line to the material. If material is not included in the article's Creative Commons licence and your intended use is not 
permitted by statutory regulation or exceeds the permitted use, you will need to obtain permission directly from the copyright holder. To view a copy of this licence, visit http://creativecommons.org/licenses/by/4.0/.

\section{References}

Alexander, W., Mazurek, M., Waber, H., Arlinger, J., Erlandson, A., Hallbeck, L., Pedersen, K., Boehlmann, W., Fritz, P. \& Geyer, S. 1998. Maqarin natural analogue study: phase III. Swedish Nuclear Fuel and Waste Management Co.

Appelo, C. \& Postma, D. J. B., Roterdam 2005. Geochemistry, groundwater and pollution, CRC.

Bauer, A., Berger, G.: Kaolinite and smectite dissolution rate in high molar KOH solutions at 35 and $80 \mathrm{C}$. Appl. Geochem. 13, 905-916 (1998)

Beckingham, L.E., Mitnick, E.H., Steefel, C.I., Zhang, S., Voltolini, M., Swift, A.M., Yang, L., Cole, D.R., Sheets, J.M., Ajo-Franklin, J.B.: Evaluation of mineral reactive surface area estimates for prediction of reactivity of a multi-mineral sediment. Geochim. Cosmochim. Acta 188, 310-329 (2016)

Bethke, C. 1996. Geochemical reaction modeling: Concepts and applications, Oxford University Press on Demand.

Brown, G. E., Trainor, T. P. \& Chaka, A. M. 2008. Chapter 7 - Geochemistry Of Mineral Surfaces And Factors Affecting Their Chemical Reactivity. In: Nilsson, A., Pettersson, L. G. M. \& Nørskov, J. K. (eds.) Chemical Bonding at Surfaces and Interfaces. Amsterdam: Elsevier.

Carroll, S.A., Walther, J.V.: Kaolinite dissolution at 25 degrees, 60 degrees, and 80 degrees C. Am. J. Sci. 290, 797-810 (1990)

Chaparro, M.C., Saaltink, M.W., Soler, J.M.: Reactive transport modelling of cement-groundwater-rock interaction at the Grimsel Test Site. Phys. Chem. Earth, Parts a/b/c 99, 64-76 (2017)

Chen, X., Thornton, S.F., Small, J.: Influence of hyper-alkaline $\mathrm{pH}$ leachate on mineral and porosity evolution in the chemically disturbed zone developed in the near-field host rock for a nuclear waste repository. Transp. Porous Media 107, 489-505 (2015)

Chen, X. \& Thornton, S. 2018. Multi-Mineral Reactions Controlling Secondary Phase Evolution in a HyperAlkaline Plume. Environmental Geotechnics.

Chermak, J.: Low temperature experimental investigation of the effect of high $\mathrm{pH} \mathrm{KOH}$ solutions on the Opalinus shale, Switzerland. Clays Clay Miner. 41, 365-372 (1993)

Crossland, I.G.J.C.C.R.: Cracking of the Nirex Reference Vault Backfill: a Review of Its Likely Occurrence and Significance. 250, 1 (2007)

De Windt, L., Marsal, F., Tinseau, E., Pellegrini, D.: Reactive transport modeling of geochemical interactions at a concrete/argillite interface, Tournemire site (France). Phys. Chem. Earth, Parts a/b/c 33, S295-S305 (2008)

Delany, J., Lundeen, S.: The LLNL thermochemical database. Lawrence Livermore National Laboratory Report UCRL- 21658, 150 (1990)

Dozol, M. \& Hagemann, R. 1993. Radionuclide migration in groundwaters: Review of the behaviour of actinides (Technical Report). Pure and Applied Chemistry.

Eberl, D., Hower, J.: The hydrothermal transformation of sodium and potassium smectite into mixed-layer clay. Clays Clay Miner. 25, 215-227 (1977)

Felipe-Sotelo, M., Hinchliff, J., Field, L., Milodowski, A., Preedy, O., Read, D.: Retardation of uranium and thorium by a cementitious backfill developed for radioactive waste disposal. Chemosphere 179, 127-138 (2017)

Fernandez, R., Cuevas, J., Rodriguez, M., Vigil De La Villa, R. \& Cunado, M. A. 2012. The stability of zeolites and $\mathrm{CSH}$ in the high $\mathrm{pH}$ reaction of bentonite.

Francis, A., Cather, R. \& Crossland, I. J. N. S. R. S., United Kingdon Nirex Limited, 57p 1997. Development of the Nirex Reference Vault Backfill; report on current status in 1994.

Gaucher, E.C., Blanc, P.: Cement/clay interactions - a review: Experiments, natural analogues, and modeling. Waste Manage. 26, 776-788 (2006)

Glasser, F.P.: Mineralogical aspects of cement in radioactive waste disposal. Mineral. Mag. 65, 621-633 (2001)

Gysi, A.P., Stefánsson, A.: Experiments and geochemical modeling of $\mathrm{CO} 2$ sequestration during hydrothermal basalt alteration. Chem. Geol. 306, 10-28 (2012)

Harris, A., Hearne, J. \& Nickerson, A. 2001a. The effect of reactive groundwaters on the behaviour of cementitious materials. AEA Technology Report AEAT/R/ENV/0467. 
Harris, A., Manning, M. \& Thompson, A. 2001b. Testing of models of the dissolution of cements-leaching behaviour of Nirex Reference Vault Backfill. AEA Technology Report, AEAT/ERRA-0316. Nirex Ltd. Harwell, UK.

Helinski, M., Fahey, M., Fourie, A.: Numerical modeling of cemented mine backfill deposition. J. Geotechn. Geoenvironm. Eng. 133, 1308-1319 (2007)

Hodgkinson, E.S., Hughes, C.R.: The mineralogy and geochemistry of cement/rock reactions: high-resolution studies of experimental and analogue materials. Geolog. Soc, London, Spec. Publicat. 157, 195-211 (1999)

Idiart, A., Laviña, M., Kosakowski, G., Cochepin, B., Meeussen, J. C., Samper, J., Mon, A., Montoya, V., Munier, I. \& Poonoosamy, J. 2020. Reactive transport modelling of a low-pH concrete/clay interface. Applied Geochemistry, 115, 104562.

Klajmon, M., Havlová, V., Červinka, R., Mendoza, A., Franců, J., Berenblyum, R., Arild, Ø.: Repp-Co2: Equilibrium modelling of Co2-rock-brine systems. Energy Procedia 114, 3364-3373 (2017)

Knauss, K.G., Wolery, T.J.: The dissolution kinetics of quartz as a function of pH and time at 70 C. Geochim. Cosmochim. Acta 52, 43-53 (1988)

Van Der Lee, J. 1998. Thermodynamic and mathematical concepts of CHESS.

Lichtner, P.C.: The quasi-stationary state approximation to coupled mass transport and fluid-rock interaction in a porous medium. Geochim. Cosmochim. Acta 52, 143-165 (1988)

Mohnot, S., Bae, J., Foley, W.: A study of alkali/mineral reactions. SPE Reserv. Eng. 653, 663 (1987)

Monte, L., Brittain, J.E., Hakanson, L., Smith, J.T., Van Der Perk, M.: Review and assessment of models for predicting the migration of radionuclides from catchments. J Environ Radioact 75, 83-103 (2004)

Nakahira, A., Naganuma, H., Kubo, T., Yamasaki, Y.: Synthesis of monolithic tobermorite from blast furnace slag and evaluation of its Pb removal ability. J. Ceram. Soc. Jpn. 116, 500-504 (2008)

Nardi, A., Idiart, A., Trinchero, P., De Vries, L.M., Molinero, J.: Interface COMSOL-PHREEQC (iCP), an efficient numerical framework for the solution of coupled multiphysics and geochemistry. Comput. Geosci. 69, 10-21 (2014)

Parkhurst, D. L. \& Appelo, C. 2013. Description of input and examples for PHREEQC version 3: a computer program for speciation, batch-reaction, one-dimensional transport, and inverse geochemical calculations. US Geological Survey.

Pfingsten, W., Paris, B., Soler, J.M., Mäder, U.K.: Tracer and reactive transport modelling of the interaction between high-pH fluid and fractured rock: field and laboratory experiments. J. Geochem. Explor. 90, 95-113 (2006)

Pitty, A. \& Alexander, W. 2010. A natural analogue study of cement buffered, hyperalkaline groundwaters and their interaction with a repository host rock IV: an examination of the Khushaym Matruk (central Jordan) and Maqarin (northern Jordan) sites. NDA-RWMD Technical Report, NDA, Moors Row, UK.

Putyrskaya, V., Klemt, E.: Modeling 137Cs migration processes in lake sediments. J Environ Radioact 96, 54-62 (2007)

Rose, N.: Dissolution rates of prehnite, epidote, and albite. Geochim. Cosmochim. Acta 55, 3273-3286 (1991)

Savage, D.: A review of analogues of alkaline alteration with regard to long-term barrier performance. Mineral. Mag. 75, 2401-2418 (2011)

Savage, D., Cave, M.R., Milodowski, A.E., George, I.: Hydrothermal alteration of granite by meteoric fluid: an example from the Carnmenellis Granite, United Kingdom. Contrib. Miner. Petrol. 96, 391-405 (1987)

Savage, D., Bateman, K., Hill, P., Hughes, C., Milodowski, A., Pearce, J., Rae, E., Rochelle, C.: Rate and mechanism of the reaction of silicates with cement pore fluids. Appl. Clay Sci. 7, 33-45 (1992)

Savage, D., Noy, D., Mihara, M.: Modelling the interaction of bentonite with hyperalkaline fluids. Appl. Geochem. 17, 207-223 (2002)

Savage, D., Walker, C., Arthur, R., Rochelle, C., Oda, C., Takase, H.: Alteration of bentonite by hyperalkaline fluids: a review of the role of secondary minerals. Phys. Chem. Earth, Parts a/b/c 32, 287-297 (2007)

Savage, D., Benbow, S., Watson, C., Takase, H., Ono, K., Oda, C., Honda, A.: Natural systems evidence for the alteration of clay under alkaline conditions: an example from Searles Lake, California. Appl. Clay Sci. 47, 72-81 (2010)

Savage, D., 1997. Review of the potential effects of alkaline plume migration from a cementitious repository for radioactive waste. Research \& Development Technical Report P, 60.

Silva, R. J. J. M. O. P. L. A. 1991. Mechanisms for the retardation of uranium (VI) migration. 257.

Small, J., Bryan, N., Lloyd, J., Milodowski, A., Shaw, S., Morris, K.: Summary of the BIGRAD project and its implications for a geological disposal facility. National Nuclear Laboratory, Report NNL 16, 13817 (2016) 
Vasconcelos, R.G.W., Beaudoin, N., Hamilton, A., Hyatt, N.C., Provis, J.L., Corkhill, C.L.: Characterisation of a high $\mathrm{pH}$ cement backfill for the geological disposal of nuclear waste: the Nirex reference vault backfill. Appl. Geochem. 89, 180-189 (2018)

Velde, B.: Experimental determination of muscovite polymorph stabilities. American Mineralogist: J. Earth and Planet. Mater. 50, 436-449 (1965)

Walker, G.P.: Zeolite zones and dike distribution in relation to the structure of the basalts of eastern Iceland. J. Geol. 68, 515-528 (1960)

Wilson, J.C., Benbow, S., Metcalfe, R.: Reactive transport modelling of a cement backfill for radioactive waste disposal. Cem. Concr. Res. 111, 81-93 (2018)

Wilson, J., Benbow, S. \& Metcalfe, R. 2017. Understanding the Long-term Evolution of Cement Backfills: Alteration of NRVB Due to Reaction with Groundwater Solutes. Report.

Worley, W. G. 1994. Dissolution kinetics and mechanisms in quartz-and grainite-water systems. Massachusetts Institute of Technology.

Publisher's Note Springer Nature remains neutral with regard to jurisdictional claims in published maps and institutional affiliations.

\section{Authors and Affiliations}

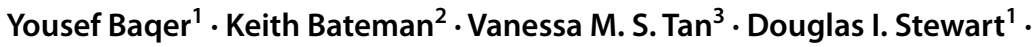 Xiaohui Chen ${ }^{1} \cdot$ Steven F. Thornton ${ }^{4}$}

\section{Xiaohui Chen}

x.chen@leeds.ac.uk

1 School of Civil Engineering, University of Leeds, Leeds LS2 9JT, UK

2 Japan Atomic Energy Agency, Radionuclide Migration Research Group, Tokai-Mura, Ibaraki, Japan

3 University of Abertay, Dundee, UK

4 Dept of Civil and Structural Engineering, Groundwater Protection and Restoration Group, The University of Sheffield, Sheffield, UK 